Aletria, Belo Horizonte, v. 30, n. 1, p. 155-171, 2020

(c) (1)

\title{
Um livro por vir: autobibliografia(s) de Silviano Santiago
}

\section{A Book to Come: Silviano Santiago's Autobibliographies}

\section{Emílio Maciel}

Universidade Federal de Ouro Preto (UFOP), Ouro Preto, Minas Gerais / Brasil emaciel72@gmail.com

http://orcid.org/0000-0003-4384-1945

Resumo: Leitura de Uma literatura nos trópicos, de Silviano Santiago, esse ensaio explora as tensões entre dito e implicado na arquitetura do livro, tomando como ponto de partida, de um lado, certos ecos telescópicos ligando algumas passagens decisivas, e de outro, a invisível teia de reverberações criada por tais ecos ao longo de todo o volume. Ao mesmo tempo, ao destacar a curiosa mescla de reverência e transgressão que constitui essa prosa, traço evidente no modo como Silviano cita e exorbita autores como Antonio Candido e Jacques Derrida, procura-se demonstrar como, nesse livro fundador, a autoridade associada ao amplo e ousado escopo de sua assinatura caminha lado a lado com uma profunda e paciente atenção aos impasses e pontos cegos que perturbam, em nível molecular, todo e qualquer texto.

Palavras-chave: assinatura; contexto; leitura; alegoria.

Abstract: A reading of Silviano Santiagos's Uma literatura nos trópicos, this paper explores the tensions between stated and implied in the architecture of the book as a whole, taking as a point of departure, on the one hand, the telescopic echoes linking some decisive passages of these essays and, on the other, the invisible network of reverberations created by these connections throughout the volume. At the same time, by underscoring the curious blend of reverence and transgression which constitutes this prose, a feature evinced in the debonair with which Silviano quotes and oversteps authors like Antonio Candido and Jacques Derrida, one intends to show how, in this groundbreaking book, the authority associated with the bold and wide-ranging scope of its signature goes hand in hand with a deep and patient attention to the dead-ends and blind spots disturbing, on its very molecular level, each and every text.

Keywords: signature; context; reading; allegory. 
Reunindo 11 textos heterogêneos, mas fortemente interconectados, Uma literatura nos trópicos, de Silviano Santiago, mantém-se ainda hoje como a melhor porta de entrada para a obra do crítico, ao compilar, em pouco mais de 200 páginas, todas as grandes linhas de força de seu trajeto. Tendo como ponto de partida o ambicioso voo teórico de "O entre lugar do discurso latino-americano", talvez seu texto mais influente e discutido, o livro se desdobra em forma de uma audaciosa curva em crescendo, na qual, após reler e ressignificar dois romances decisivos na literatura em língua portuguesa - nada mais nada menos que Dom Casmurro e $O$ Primo Basílio -, o autor se lança num cerrado corpo a corpo com as obras à primeira vista mais laterais de Raul Pompéia e José Américo de Almeida, convertidas em via transversa para descristalizar certas idées reçues da historiografia brasileira. Com efeito, seja lendo a contrapelo Eça e Machado, seja submetendo o sintagma "romance de 30" ao abalo gerado pela leitura em microscopia - na qual os sinais gráficos são tão ou mais importantes que as linhas mestras do enredo -, o que se tem aqui, sem exagero, é uma sequência capaz de colocar Silviano na linha de frente da melhor ensaística brasileira do período, revelando uma voz apta não só a revirar por completo o entendimento de eventos-chave como a colocar todo seu ferramental crítico a serviço de revigorantes choques contraintuitivos.

Num ritmo que jamais perde de vista a exigência do saber-comsabor inata à forma-ensaio, é interessante notar, porém, como, depois dessa abertura impressionante, o livro conhecerá uma síncope algo inesperada no texto dedicado a Waly Salomão e Gramiro de Matos, quando, ao aventurar-se a um embate head-on com as inquietações do presente - tendo por foco autores não apenas novíssimos como inclassificáveis -, o crítico adentra, sem maiores avisos, por um terreno muito mais escorregadio e perigoso, ativando desse modo um imediato efeito de ricochete sobre referência à "perda de segurança de julgamento" contida na "Nota prévia". Expressão capaz de soar, a luz das primeiras 80 páginas, quase como um lance de modéstia afetada - ainda mais tendo-se em vista o poderoso efeito de autoridade criado pela destreza com que 
o crítico terça armas com nomes como Schwarz, Candido, Meyer, entre outros -, trata-se de uma advertência, como veremos, que ganhará um aspecto inquietantemente mais literal à luz do arco temático coberto pelas 5 peças restantes, quando, ao díptico dedicado a Caetano, se somam um ensaio bastante incisivo sobre o então quase estreante Sérgio Sant' Anna e outro mais panorâmico sobre a dita geração marginal. Tendo por arremate o texto em aparência bem mais ortodoxo sobre o estruturalismo e sua sobrevida, é curioso notar, ainda, como, sanduichados entre as duas densas incursões teóricas que abrem e concluem o livro, os 9 ensaios mais específicos parecem selar sub-repticiamente uma suave variante do topos da troca de guarda, desenhando um arco no qual, pouco a pouco, muito daquilo que se tinha como certo sobre a literatura - como por exemplo a centralidade da forma-livro sobre dispositivos como o disco, a revista e a performance - vê-se lenta mas incisamente submetido a uma sutil operação de esgarçamento.

E é assim que, à medida que vamos avançando sobre esses novos eixos temáticos, o campo aparentemente sagrado dos textos canônicos se vê forçado a se haver com as infiltrações inesperadas, anunciadas pelo ensaio/ponto de inflexão "Os abutres", corte a partir do qual, em certa medida, a prosa do livro começa a se abrir algo temerariamente para uma zona de exterioridade difusa, cujo efeito é abalar o próprio fundamento de solidez do que até então se dava por certo. Mas não apenas: que isso implique também em colocar um perturbador sinal de aspas na própria categoria "literatura", aí ressignificada como efeito de um jogo de copertencimento íntimo entre a escolha e a exclusão, entre centramento e banimento, é uma dobra, sem dúvida, que confere uma intensa maisvalia narrativa ao que poderia a princípio até soar como mero arranjo paratático, tal a diversidade de temas e dicções que a prosa de Silviano abrange. Vale observar, ainda, que, se levarmos em conta o peso aí conferido ao dispositivo do mise-en-abyme, saudado numa nota de pé de página como o termo mediador ideal entre a parte e o todo, entre detalhe e plano geral, não deixa de ser interessante notar como, ao ser louvado pela "capacidade de transpor para a escala dos personagens o motivo da obra", e assim "estabelecer com mais segurança as proporções" (SANTIAGO, 1978, p. 64), esse comentário pode funcionar em retrospecto quase como um pseudo-paratexto para os fortes efeitos de sincronia perpassando o livro inteiro, com uma insistência que nos obriga também a mensurar as implicações e/ou intimações totalizantes de certas observações 
esporádicas, capazes de cavar túneis inesperados ligando pontos distantes. Numa aproximação inicial, portanto - e não há aqui, claro, qualquer propósito de ser exaustivo, nem conclusivo -, isso leva, sem dúvida, a converter em limiar incerto a própria distinção estabelecida entre, de um lado, os 2 textos por assim dizer mais (meta)teóricos e, de outro, os 9 ensaios monográficos por eles emoldurados, reversão que sem dúvida acrescenta uma deliciosa nota irônica à cautela de abrir e fechar o livro com dois alentados planos gerais sobre o dito "estado da arte", seja do comparatismo, seja da teoria literária. Terminada a leitura em sequência, por sinal, e percebidas portanto todas as rimas de longa distância que ao mesmo tempo escandem e interrompem o curso dessa prosa, é quase como se, no limite, fosse o próprio efeito desterritorializante dos textos do miolo - nivelando quase em igualdade de condições poemas e letras de música, e delineando inusitados excursos teóricos sobre temas como "desbunde, "transa" e "curtição" - que ganhasse algo de um segredo de polichinelo à luz da costura centrípeta ativada nas especulações que emergem de cada embate singular, ensejando sobreposições tão inesperadas quanto precisas entre duas ou mais peças isoladas. Ou isso, pelo menos, é o que parece se dar com especial clareza nessa pequena passagem retirada do ensaio 6 , no qual não é exagero também identificar uma das mais arrojadas dobradiças do livro inteiro:

Conforme assinalou muito bem Antonio Candido, na Formação da literatura brasileira, Gregório de Matos não existiu "literariamente" até o Romantismo, defasagem entre a escritura e a leitura, entre a obra e a aceitação dessa obra pela "literatura" que lembra defasagem semelhante a que existiu entre a publicação do Guesa Errante e sua descoberta pelo grupo Noigrandes. Poderíamos sem susto afirmar que tanto Gramiro quanto Waly são consequência direta do espírito revisionista que tem primado não só pelo fato de rever criticamente a literatura brasileira, como ainda por pensar novos modos de organização de uma História de Literatura Brasileira, visto que os métodos de ordenação que conhecemos (o método histórico, o de estilo de época etc) tem cometido barbaridades com o nosso acervo. (SANTIAGO, 1978, p. 130)

Com um tom que poderia ser até facilmente confundido com o de um elogio aberto, quando a retomada do argumento-chave do grande 
crítico uspiano parece fazer as vezes de alavanca para tudo o que virá a seguir, não é exagero notar como, nessa passagem, certa concordância de fundo inicial acaba por se colocar a serviço de uma ressignificação drástica e não exatamente gentil, cujo fulcro pode ser identificado, sem dúvida, no longo aposto explicativo protagonizado pelo termo "defasagem", aí vertido em pinguela capaz, em menos de 4 linhas, não só de identificar um padrão recorrente assombrando e conectando "Barroco" e "Romantismo", como explicitar um certo passivo sacrificial latente na própria ideia de rede transmissora privilegiada pelo autor de Recortes. Tendo como interlocutor confesso o capítulo "Literatura como sistema", da Formação da literatura brasileira, o trecho por mim destacado, no início do excerto, não deixa de ser também um ótimo exemplo da dialética de reverência e transgressão dramatizada no famigerado derradeiro parágrafo de "O entre-lugar do discurso latinoamericano", aqui equilibrando-se num fio tênue onde, a rigor, reconhecer a densidade e sofisticação do constructo teórico de Candido - cuja força passa exatamente pela capacidade de já colocar logo no início do jogo todas as suas cartas à mesa - tampouco impede a paráfrase de virar o texto que retoma contra si mesmo; repto que se dá aqui justamente por meio da ágil mudança da tônica do interior para o exterior do sistema. De um extremo a outro do excerto, por sinal, - e nesse ponto difícil subestimar o peso polêmico investido sobre o que Waly chamara de o "certeiro corte dos concretos" (SANTIAGO, 1978, p. 130) - , a impressão é que, ao ser contraposto e tensionado pelo que deixa de fora, é como se o próprio tripé "autor-obra-público", tão caro a Candido, tivesse que se haver com o ônus gerado por uma linha de fuga tão consistente quanto obsedante, e que encontra exatamente seu eixo nesses dois grandes intempestivos que são Gregório e Souzândrade. Apenas que, se no caso do primeiro, pelo menos, tal exclusão poderia ser ainda justificada em termos mais factuais - na falta de uma correia de transmissão apta a fazer de sua obra um possível pano de fundo para um Claudio ou um Gonzaga -, no que se refere ao maranhense, ao contrário, o silêncio tomará antes a forma, em Candido, de uma recusa estética deliberada, amparada em critérios de legibilidade que, se podem fazer até algum sentido no cotejo com a miragem de um público médio, tornam-se bem menos factíveis no embate com os possíveis jovens leitores sessentistas de Pound, Mallarmé, Finnegan's wake etc. Ou para ficar num terreno ainda mais tangível - e não mais estritamente literário -, na própria radicalização experimental 
proposta pelo Caetano concretista-souzandradeano de "'Araçá Azul" não por acaso, um disco que bateu todos os recordes de devolução nas lojas quando de seu lançamento, em janeiro de 1973. Tomadas as devidas distâncias, porém, se é certo que, amparados no suave mare magno da leitura a posteriori, não creio ser difícil conferir um certo a-mais de sentido a esses e outros aerólitos, o mesmo não se pode dizer, contudo, da escorregadia sinuosidade do longo e venenoso trecho há pouco citado, cujo frescor passa tanto pela aparente sem-cerimônia do seu tom geral quanto pela violentíssima inversão contida na referência ao sem número de "barbaridades cometidas" contra o "nosso acervo". E não parece que trate-se aqui apenas de um modo de dizer: convocando expressões que soam quase meticulosamente calculadas para açular e acirrar todos os ânimos, esse fecho caminha nos exatos antípodas do drive revisionista, celebrado por Silviano no início do trecho, abrindo assim um flanco no qual, a fortiori, é como se fosse exatamente aos supostos profanadores do cânone que ficasse reservada a função de zelar de fato pela "nossa" riqueza comum, cabendo assim aos mais ortodoxos a duvidosa honra de fazer as vezes de bárbaros. O mais curioso, porém, é que, se lido tendo como pano de fundo o parágrafo final do artigo em questão - trecho que, de tão glosado e citado nas últimas 4 décadas, parece ter se transformado quase em aforisma no seu próprio direito -, mesmo o solavanco gerado pela boutade do crítico se dá a ver de relance como talvez a mais perversa ironia do livro inteiro, a ter lugar quando, retomando com sinal trocado o célebre último parágrafo, Silviano retorna agora vestindo a carapuça de um arconte zelando pela integridade do munus, no que soa quase como um aceno escarninho ao cripo-louvor da agressão/transgressão no fecho deste mesmo ensaio:

Entre o sacrifício e o jogo, entre a prisão e a transgressão, entre a submissão ao código e a agressão, entre a obediência e a rebelião, entre a assimilação e a expressão - ali, nesse lugar aparentemente vazio, seu templo e seu lugar de clandestinidade, ali se realiza o ritual antropófago da literatura latino-americana. (SANTIAGO, 1978, p. 28)

Concentrando/comprimindo num só lance de vista todas as tensões do livro, esse trecho funciona quase ao estilo de um buraco negro sugando avidamente tudo o que está no entorno, sem deixar, porém, de adquirir valências levemente distintas dependendo da figura para o qual 
venha ou não servir de fundo. No que se refere aos dois ensaios sobre Caetano, por exemplo, é interessante notar como, em contraste com a dicção falsamente relaxada de "Caetano Veloso enquanto superastro", o desenho argumentativo de "Bom conselho" não irá se fazer de rogado em propor de novo certa contraposição dicotômica, em que a abertura do compositor baiano para o suposto lixo cultural e o sem-sentido opera em contraste derrogatório com as canções/letras, para Silviano, bem mais domesticadas do jovem Chico Buarque - que nessa clave lembrariam um pouco o Dylan pré-Newport na sua disposição em pregar aos já convertidos. Ênfases e discordâncias, porém - num livro que, sem perder de vista a longa duração, tampouco vê problema em dar livre curso ao "sim e ao não do palato" -, é certo que isso corre de par a um raciocínio, logo mais tarde, que irá ecoar tanto nas ressalvas impostas ao projeto de Sérgio Sant'Anna - no qual o crítico enxerga quase o modelo reduzido de uma fuga cerebrina face a impureza do mundo - quanto no louvor talvez um pouco condescendente da geração mimeógrafo. Movimento que poderíamos aliás expandir quase ad infinitum quanto mais se aprofunda o mergulho em filigrana, creio que um confronto que se torna, a essa altura, quase inevitável diz respeito ao modo como, ao operar no livro como uma espécie de grande encruzilhada onde todos os caminhos se encontram, esse trecho perfaz, a seu modo, um ágil aceno transcriador ao raciocínio exposto por Derrida nos três últimos parágrafos de "A estrutura, o signo e o jogo no discurso nas ciências humanas", ensaio que, no longínquo ano de 1966, marcaria, como se sabe, a conversão do jovem filósofo em estrela acadêmica em ascensão. Retornando no desenlace do livro numa peça sobriamente batizada de "Análise e interpretação", tal como se dá a ver em "O entre-lugar do discurso latino-americano", porém, trata-se de uma voz, a princípio, que aí emerge quase ao feitio de um sample musical sobre o qual Silviano canta por cima, até retornar em aparência bem mais apaziguada, via citação direta, na peça que fecha o volume - naquele que é, também, o primeiro momento no livro onde um autor estrangeiro surge diretamente enxertado em tradução brasileira. Detalhe cujas implicações estão longe de ser anódinas para o curso do meu próprio argumento, para o que nos interessa por ora, contudo, é intrigante perceber como, aclimatado na prosa tão dúctil do nosso autor, o cauteloso ir e vir derridiano entre a origem e o jogo - ou seja, entre um impulso que tenta estancar/capturar em fixidez o ricochete dos signos, e outro que assume e dramatiza o caráter ao mesmo tempo arbitrário e necessário desses e 
outros (re)cortes - retorna devidamente embalado no toque, digamos, de cor local conferido à imagem do ritual antropófago, ritual emergindo em Silviano como duplo diferido da monstruosidade "informe, muda, infante e terrificante" (SANTIAGO, 1978, p. 249) que fecha o texto de Derrida, quase como uma palavra na lápide. Não que se trate propriamente de uma conversão sem resto: afinal, se em Derrida tal imagem tinha como referente último as ambivalências e ambiguidades das dores do nascimento, em Silviano, ao contrário, a conotação reiterativa ligada ao significante "rito" parece sobretudo alçar à condição de estrutura o que no outro texto exibia ainda o caráter irrepetível de um evento incoativo, traço conhecendo, sem dúvida, outra discreta reiteração quando, prensado pela necessidade de escolher entre as duas grandes sendas que ele mesmo elencou, Derrida prefere, delicada mas decididamente, afastar de si esse cálice, numa frase escrupulosa e evasiva como poucas ("Pelo que me diz respeito, não creio, muito embora essas duas interpretações devam acusar sua diferença e aguçar sua irredutibilidade, que hoje haja alguma coisa a escolher") (DERRIDA, 2002, p. 249). Gerando assim um forte contraste com a urgência do dêitico "ali" mobilizado no trecho de Silviano, termo de certo modo capaz de reancorar o texto em suas condições de enunciação específicas, outro detalhe que aí chama atenção, apesar e/ou por causa de sua própria sutileza, é a breve miragem criada, no referido parágrafo, pelo travessão antecedendo de perto a inscrição desse "ali", e como que sugerindo a escansão parentética de um possível aposto explicativo, incumbido talvez de conferir o lastro devido à terra de ninguém recoberta pela reiteração do "entre", em cinco tensos sintagmas. Ou quem sabe até tentar comprimir tais sintagmas num único golpe de vista. Na contabilidade final, entretanto, visto que o parêntese aí se mantém aparentemente ainda aberto uma vez o texto findo, a impressão é que, mais do que propriamente colocar-se como ponto de apoio, a relativa agramaticalidade desse traço/travessão tende agora a funcionar menos como um sinal sintático do que rítmico, marcando um nó temporal que, simultaneamente incisivo e suspensivo, dá bem a medida da agilidade e do jogo de cintura da apropriação de Silviano. Que, ao incorporar, à moda antropófaga, a assinatura Derrida, cria assim, de pronto, outro acirrado agón de contágio recíproco entre o dito e o modo de dizer. No cotejo com espectro derridiano de certo - cuja escrita tem exatamente nesse atritar do quê e do como uma de suas linhas mestras -, é uma tensão que opera, na visão panorâmica, tanto como atestado de exorbitância quanto de 
fidelidade, correndo de par ao abalo ziguezagueante gerado por um denso rosário de referências, que passando de Valéry a Cortázar, de Heródoto, Borges a Oswald, delineia um percurso bem mais centrífugo e íngreme do que o de Derrida. E isso em que pese, claro, a inegável destreza que ambos demonstram para extrair consequências quase incalculáveis de detalhes aparentemente menores - desde o uso ou não de aspas no termo "literatura" até o critério em jogo quando se trata definir quando se deve traduzir ou não a várias citações em francês. Ou ainda, para ficar num ponto que tentarei explorar com mais calma nas próximas páginas, sobre as possíveis implicações retóricas, alegóricas e narrativas de se citar um autor estrangeiro na nossa própria língua de origem.

Estabelecer então qual seria de fato o real alcance crítico de filigranas como essas, tendo-se em vista ainda a baixa cotação de que hoje desfrutam, de um modo geral, as imersões micrológicas, é um problema que, a julgar pelo que expõem e performam ambos os ensaios, está longe de prestar-se docilmente a uma codificação didática, e muito menos de se estabilizar em heurística confiável. Ao contrário: implicando em nada menos que colocar em suspenso o que é ou não pertinente para a captura do sentido de um texto, o que daí resulta é antes uma dúvida, de fora a fora, que, espraiando-se sem remissão por todas áreas e níveis textuais, pode muito bem vir a desaguar, por exemplo, na pergunta sobre até que ponto se pode dizer que uma dada leitura teria "ido longe demais" - ou, mudando um pouco a angulação do problema, em que medida isso seria um critério tão fluido, histórico e retificável quanto a própria noção de ruído. À primeira vista, porém - e penso que há pouco ou quase nada de consolador numa constatação como essa -, é preciso reconhecer que, ao pressupor o necessário mergulho em slow motion pela textura do escrito, tais impasses correm por vezes o risco de soar quase como um peixe fora d'água na episteme teórica do presente, a qual, ironia das ironias, ao institucionalizar como positividade específica muitas das preocupações de Derrida e Silviano com esse exterior-sempre-em-fuga, acaba também por arredondar-para-baixo o potencial reversivo de sutilezas desse tipo, convertidas muitas vezes pelos cultural studies em mera sobrevida tardia da velha "leitura cerrada". Sem descartar, claro, a inevitável pertinência estratégica dessas e outras ênfases - em que pode-se ver também a nêmese exigida por décadas de silenciamento e/ou desconsideração -, o mínimo que se pode dizer é que, ao colocá-lo ao mesmo tempo em sintonia e embate com o seu próprio tempo - do qual ele aparece, aliás, 
por vezes, quase como um precursor borgiano em sua preocupação com o marginal,o excluído e o residual -, esse cuidado com detalhes mantidos, via de regra, fora do radar das antenas hegemônicas responde por muito da sadia aura de inatualidade de que se reveste hoje um livro como Uma literatura nos trópicos, em que a permanente disponibilidade face os rumores e burburinhos do entorno não é em nada contraditória com a aposta nos benefícios a serem hauridos da referida leitura em câmera lenta, apta a potencializar detalhes que outros talvez descartassem como textura irrelevante. Habilidade que corre de par também ao zelo para resistir, quase com sucesso, às referencializações apressadas, em prol de uma imersão lenta e minuciosa no peso e implicações de certos padrões recursivos, parece-me que uma bela exemplificação desse ethos pode ser encontrada na brilhante exploração proposta pelo crítico das pausas, parênteses e reticências que pontuam A bagaceira, num ensaio que constitui, de per se, também um pequeno tour de force sobre a capacidade de rebater e implicar o micro e o macro do texto, com um vagar e escrúpulo que soam aliás deliciosamente anacrônicos em plena era dos memes. Relevado assim o peso que nisso poderia ter também o recuo de uma certa dominante formalista/estrutualista/imanentista, é bem verdade, ainda, que, não sendo esse um ponto lá muita realçado na vasta fortuna crítica do livro, ele nem por isso deixa de reservar um bônus de surpresas aos que por ventura se detenham sobre certas flutuações de tom e/ou acenos de longa distância, operando aqui quase como pequenas pedras de tropeço em meio à sprezzatura própria à dicção ensaística e, ato contínuo - na insistência como tais impasses aí "fazem sistema", entre uma digressão e outra - costurando uma trama de piscadelas oblíquas entre pontos distantes no livro. Numa escala, por assim dizer, mais geral, portanto - que esgarce ou dissolva as fronteiras dos textos em favor de um eventual efeito sinfônico que a sua somatória produza -, trata-se de um percurso, sem dúvida, que conhecerá outro belo paroxismo de dissonância no contraste unindo-contrapondo a "Nota prévia" à hipérbole da citação final de Derrida, enlaçadas num todo no qual, num primeiro relance, o tom cauteloso e quase professoral do miniprefácio soa quase tímido e desajeitado no cotejo com o pathos abertamente blanchotiano do comentário sobre Jabès, que, em seu apelo a "deixar que a palavra fale sozinha" bem como "ao cair fora da linguagem" (DERRIDA, 1978, p. 207) que constitui o próprio escrever, não deixa de ter também algo de um dar-de-ombros. E o que é pior: tendo por foco um extrato, acaso ou 
não, que trata justo da inevitável auto-despossessão do texto e da escrita em relação a si mesmos. Despontando, em certa medida, quase como um eco remoto ao narrador padrasto de Cervantes - instância que, face os mil mal-entendidos gerados por tais papéis avulsos, teria, sem dúvida, o bom gosto de apresentar-se como mero ponto de articulação provisória de um processo que não controla de todo -, cumpre reconhecer ainda, no que se refere a Derrida, que, ao impor-se como o ponto de fechamento de uma frase a princípio iniciada por Silviano (“escrever é pois..."), tal extrato constitui por si só, também a seu modo, outro vórtice de ambiguidades e tensões não menos inextrincáveis, em que a aparente modéstia contida nesse ceder voz ao outro é equilibrada por um súbito giro de posições entre o agir e o ser agido. Até culminar no ponto onde, salvo engano, a desaparição elocutória implícita nesse "deixar-falar-sozinha", chancela mallarmeanamente a tomada final do poder daquele que deveria ser, ao menos em tese, o alvo e objeto da ação, numa guinada, enfim, que, à luz da vertigem deflagrada nessa prosopopeia final - onde o eu é menos possuído que possuidor em sua relação com a instância-linguagem -, ajuda, sem dúvida, a explicar muito da estranheza gerada pela aparente contenção de tom da citada "Nota prévia", quando, passando ao largo dessa indiscernibilidade, somos colocados diante de um circuito constituído por partes claramente diferenciadas umas em relação às outras. Mesmo se não exatamente por muito tempo:

O intérprete é, em suma, o intermediário entre texto e leitor, fazendo ainda deste o seu próprio leitor. Procura formalizar e discutir, para o curioso, os problemas apresentados pela obra, deixando com que esta se enriqueça de uma camada de significação suplementar e que aquele encontre trampolins menos intuitivos para o salto da leitura. (SANTIAGO, 1978, p. 10)

Conhecendo um de seus momentos fortes na breve menção ao suplemento derridiano - duplo que expande e contém a obra sem, no entanto, dela constituir jamais a palavra final -, não há dúvida que, no confronto com a pegada bem mais melodramática da frase a 4 mãos, esse trecho parece recolocar o problema no âmbito aparentemente bem mais terra-a-terra do gênero "modo de usar", e no qual pode-se ler ainda um subterfúgio para não desencorajar o leitor face às "n" complexidades que o livro the reserva. Deslizando quase sem ênfase alguma para um 
pequeno jogo de caixas de chinesas entre texto, mediador e receptor, é interessante notar ainda como, depois de ensaiar o que poderia ser uma transição gradativa, o parágrafo logo se deixará abalar por dentro com a imagem dos "trampolins menos intuitivos" de sua chave-de-ouro, num trecho, de uma parte, que se, por vezes, soa quase machadiano no litote com que acomoda e atenua a reivindicação de rigor ("menos intuitivos"), de outra, conhece sem dúvida uma aceleração meio brusca na sacudidela provocada pela figura dos trampolins, onde pode-se ler, aliás, uma bela prolepse do movimento não exatamente suave entre pontos não contíguos do livro, e/ou fora dele. Mais que isso: ao colocar em xeque a ideia de um trajeto linear e irreversível do início ao fim do volume, é quase como se, agora, ao deixar o impulso de leitura se perturbar, na figura do salto, pelo senso de sua própria violência e/ou contingência, tal passagem quisesse também nos convidar a ler no contrapelo a própria impressão de mudança súbita gerada pelo avanço da leitura, à medida que tais adensamentos passam a operar, meio sem querer, quase como catapultas lançando o leitor de afogadilho, de um ponto a outro, e, ato contínuo, criando algo como uma série de duplicatas sincrônicas para o que seria de supor, à primeira vista, um trajeto linear. Não é o que se poderia chamar exatamente de um terreno firme - em que pese o crucial detalhe de que, tudo somado, por manter-se pairando, quase como uma intimação constelar, sobre a linha diacrônica explícita, tal impasse corra o risco de passar quase desapercebido pela grande maioria dos leitores, no que constitui, sem dúvida alguma, uma das mais divertidas ironias do livro inteiro. Numa palavra: como se nesse vai-e-vem incessante do todo ao detalhe, fosse a própria discrepância verificada entre o tom do início e do fim que terminasse forçando o leitor a transpor num salto brusco a distância entre eles, num lance que opera, sem dúvida alguma, como ilustração em ato de tudo o que está em jogo nessa imagem dos trampolins. Descontado é claro esse estranho trade-off criado entre os planos da enunciação e do enunciado - onde, por exemplo, a perda de si, dramatizada na citação de final deve se haver com a sobriedade quase filológica que prevalece em grande parte de "Análise e interpretação" -, outro dilema tornado quase incontornável, a essa altura, diria respeito aos dispositivos que respondem pela condição de "menos intuitivos" dos referidos trampolins, à falta de uma sinopse apta a distribuir os pesos e medidas de cada trecho isolado. Ao menos na primeira impressão, porém, o fato é que, com a incessante proliferação de mise-en-abymes, 
é como se fosse a própria tarefa de recompor em totalidade o, digamos, "argumento do livro" que terminasse sistematicamente revogada pelo jogo de ecos, rasuras e reacentuações de um texto/trecho sobre o outro, em que muitas vezes não é mais possível saber ao certo a quem cabe a precedência: se é a leitura da obra específica que serve à especulação, ou se esta é que vem a ser daquela outra um diferimento alegórico. Padrão sem dúvida interessante demais para ser só arbitrário, tampouco penso ser coincidência, enfim, que no confronto com a leitura em devir de nomes como Derrida, Deleuze e Nietzsche, o grande ponto cego do estruturalismo, na fina análise de Silviano, incida exatamente na intimação totalizante e criptocartesiana contida nos procedimentos de decupagem e agenciamento do primeiro Barthes, descrevendo um raio no qual, via de regra, se o texto deve ser primeiro decomposto em suas partes mínimas, é só para depois poder se deixar recompor em simulacro inteligível. De uma etapa a outra, contudo, restaria ainda em aberto a pergunta - não menos que decisiva - sobre que peso dar aos resíduos que teimam em continuar indóceis a tais indexações, talvez por se inadequarem à medida estabelecida a priori para determinar a tal unidade mínima. Definir então um espelhamento inequívoco entre a parte e o todo, e assim estancar de uma vez por todas a possibilidade de que um novo sentido se insinue é um horizonte, portanto, que tende a manter-se de um modo geral, teórica e praticamente, desautorizado pela feição calculadamente evasiva desse livro ímpar, em que, para evocar a obra-prima de Velásquez, é muitas vezes o próprio ponto de fuga que parece estar, também ele, em fuga.E, no entanto, mesmo desencorajando de saída qualquer certeza inequívoca, é inegável que isso tende a criar também algo como uma estranha bifurcação dos textos em relação a si mesmos, ao estilo do que vemos ocorrer, por exemplo, na citação/paráfrase/palinódia do livro capital de Antonio Candido. Como num incessante jogo de empurra entre figura e fundo, penso que uma das menos suaves consequências disso tudo, quanto mais a leitura avança, é fazer com que, no limite, à luz do rosário de citações que o antecede, seja o próprio excerto de Derrida da página 207 que ganhe uma espécie de mais valia alegórica tão logo conectado à metáfora do ritual antropofágico tirada de " $\mathrm{O}$ entre lugar do discurso latino-americano", a ponto de tornar cada vez mais insinuante e pregnante uma certa ideia de "tomada de posse". Ou isso, salvo engano, é o que parece se dar a entrever quando, com o aparecimento de nomes como Derrida, Nietzsche, Freud e outros, na terceira e última seção, excertos 
originariamente citados em língua francesa - e devidamente traduzidos em nota de rodapé, das páginas 191 a 200 da edição de 78 -, vão cedendo vez, no corpo do ensaio, a citações diretas em tradução, que tornam-se, aliás, hegemônicas numa proporção de 10 para 12 na secção final. E aí está, sem dúvida alguma, um ponto decisivo: uma vez que dificilmente poderíamos atribuir tal discrepância a uma simples distração do crítico, talvez seja essa a deixa de que precisávamos para, face a esse outro pseudo-acaso tão chamativo, como que tentar congelar por alguns segundos o fotograma do filme, e passar a buscar então a imagem apta a amortecer um pouco o peso de uma tal discrepância, tão logo começamos a caminhar um pouco mais desimpedidos sem as parábases dos pés de página. Sem descuidar, claro, do que possa haver de salto hiperbólico na ênfase em detalhes desse tipo - que, ao escancarar os limites da simples paráfrase, parecem antes colocar em cena um possível sentido implícito e/ou latente na própria mise-en-scène da prosa -, não há dúvida que essa sensação de súbito ganho de velocidade confere uma espécie de lastro palpável ao impasse teórico que aborda, operando agora ao feitio de um lento travelling frontal sobre um o objeto de que se cobiça tomar por seu. Ao mesmo tempo, e em não menor medida, que nos força ainda a reler com as lupas devidas a aparente impressão de anticlímax gerada pelo trecho onde a deglutição culmina, imprimindo um discreto, quase deceptivo tom menor à la Eliot ("not with a bang...") à conclusão do livro: "Cair longe de sua linguagem, emancipá-la ou desampara-la, deixa-la caminhar sozinha e desmunida. Abandonar a palavra... Deixa-la falar sozinha, o que ela só pode fazer escrevendo." (SANTIAGO, 1978, p. 207)

Descontando-se o já mencionado choque ativado nessa citação a seco - em meio à qual convoca-se Derrida para fechar o sentido da frase iniciada e deixada pendente por Silviano, uma linha acima, ("Escrever é pois") -, penso que um dos aspectos mais chamativos desse excerto diz respeito exatamente à bifurcação aberta por essa inscrição de reticências, detalhe que nos obriga a reler com um certo pé atrás sua aparente profissão de "humildade". Operando quase como uma pequena violência surda sobre o uso mais tradicional desse recurso - a saber, o de indicar um salto/ supressão no texto citado -, trata-se de uma operação, toque célineano a parte, que, ao elidir no original de Derrida a frase "ser poeta é ", dá a impressão de avançar aqui um passo além da pura introjeção sem filtro, descrevendo um salto no qual, no limite - na passagem da dita apropriação à incorporação efetiva -, o texto-matriz se torna passível de 
ser submetido a todos os cortes e costumizações necessários para o que façamos falar o que queremos que fale. E isso sem embargo, claro, da própria contradição performativa latente numa paráfrase como essa, que, tendo por foco o limiar de desposessão máxima entre o eu e a linguagem, leva também o texto a negar no plano do enunciado o ato que deveras realiza. Na telescopia do livro de Silviano, por certo, se é o caso de alçarmos o rito antropófago à condição de moldura em última instância, não há dúvida de que tudo isso serve como uma boa ilustração em ato da uma quase irresistível força de contágio, delineando um trajeto no qual, pouco a pouco, o aparente jogo entre parte e todo dramatizado no elogio do mise-en-abyme estende, progressivamente, seu raio de influência até a própria textura da escrita. E vice-versa. Se está certamente bem longe de tornar mais fácil a vida do leitor, esse imbricar quase titânico de dito e dizer - em que o sentido é como uma grande carta-roubada na espessa nervura da letra - não deixa de constituir também, a seu modo, uma impressionante façanha formal, dependendo o maior ou menor êxito de cada operação de leitura menos da definição de uma ancoragem "x" ou "y" para a errância dos signos que da destreza para escavar possíveis áreas de comensurabilidade e interseção entre essas distintas escalas. Estejamos ou não, porém, adentrando uma nova e perigosa zona fantasma, o certo é que, de qualquer ângulo que se olhe, tais detalhes só fazem confirmar o rigor quase inverossímil da metáfora do salto/trampolim de leitura ativada por Silviano, aqui vertida em senha para a falta de muletas confiáveis para mediar/amortecer a passagem de uma a outra grandeza - se é que se trata mesmo de uma questão de escolha. Tendo-se em vista ainda o que emerge como um possível termo comum entre esses dois grandes embates - primeiro, com Candido, e depois com Derrida - , é possível que o maior ponto de confluência, no volta-face final, não diga senão respeito à capacidade de sensibilizar-nos para o modo como, em ambos os casos, mesmo a mais criteriosa operação de leitura terá que se haver sempre com o ônus gerado por um fechamento tão arbitrário quanto necessário; a ter lugar, por exemplo, a cada vez que se isola do texto original um suposto trecho significativo, convertendo-o assim em sinédoque mais ou menos confessa da fonte de que foi extraído. Em meio a um cenário no qual, então, quanto mais o texto se rebate sobre si mesmo, em todos os seus níveis, mais remota se torna a miragem de uma âncora capaz de contê-lo, nunca será demais ressaltar a insistência como, em Uma literatura nos trópicos, essa tensão corre de par a um 
movimento com cujas implicações estamos tentando, ainda hoje, chegar a bom termo - e que constitui exatamente a sobrevida, a meu ver, mais duradoura, do livro de Silviano. Seja quando indaga sobre as ressonâncias de uma dada definição de literatura ao status teórico a ser atribuído, entre outros, à música popular ou às novas gírias, seja ainda quando prefere simplesmente tensionar o substantivo em questão no artigo indefinido "uma", intrigante perceber também como, mesmo mantidos tais detalhes no plano da piada interna, eles não deixam de ecoar/alegorizar a própria resistência à inscrição de muitos desses temas, não obstante certo efeito de acolchoamento ativado pela recorrência, ao longo do livro, de imagens como as do rito, do jogo e da profanação. Capazes de funcionar como grandes termos tapa-buraco para várias das radicais ambivalências em que cada leitura esbarra, são imagens operando, aqui e ali, como um mix de cola centrípeta e fio de Ariadne, e cuja eficácia responde, decerto, pela agradável impressão de fluência que essa somatória de textos provoca na tomada de helicóptero, e por muito do próprio charme e fecundidade desse livro fundador, onde a força e abrangência do conjunto passam elegantemente ao largo da tentação/intenção de dizer sobre si a última palavra, para operar antes por meio de um rebater contínuo entre o dito e o dizer, parte e todo, texto e contexto, sem demérito das várias consequências e implicações disso para problemas de larga escala. A começar, por exemplo, pela própria pergunta sobre o que seria ou não, ou mesmo sobre o que poderia ou não ser e/ou fazer, "uma literatura" - com ou sem aspas. Convertendo assim, como se vê, o próprio gesto de citar em uma espécie de mise-en-scène teórica, na exata torção pela qual nos obriga a ler e repassar com estômago de ruminante detalhes que se tornam quando menos se espera a própria miragem do todo, o que daí resulta é uma tensão, seguramente, que, longe de constituir-se em apoio sólido, toma antes a forma de um estranho perde-ganha entre aparentes opostos; jogo no qual, como nos advertem no espaço de um "ou" Derrida e seu leitor, o desamparo pode ser apenas a cifra enviesada da emancipação por vir, forçados que somos então a caminhar sozinhos e desmunidos por um terreno que torna por vezes quase indiscerníveis limite e limiar. À falta portanto de um critério apto a distinguir, de uma vez por todas, o fortuito do constitutivo, o relevante do indiferente etc, nada mais justo e apropriado, enfim, que, mesmo a autoridade há mais de 4 décadas associada à assinatura "Silviano Santiago" desponte antes como o tênue e por isso mesmo rigoroso ponto de chegada de uma espécie de 
cristalização, algo paradoxal, onde o zelo para resistir bravamente a um salto sinóptico não é senão corolário da capacidade de expandir, acercar, abranger, mas jamais de todo dominar a própria dispersão que gera.

\section{Referências}

BARROS BAPTISTA, Abel. Autobibliografias. Campinas: Ed. Unicamp, 2004.

BLANCHOT, Maurice. O livro por vir. São Paulo: Martins Fontes, 2014.

CANDIDO, Antonio. Formação da literatura brasileira. São Paulo: Ouro sobre azul, 2010.

DERRIDA, Jacques. A escritura e a diferença. São Paulo: Perspectiva, 1978.

SANTIAGO, Silviano. Uma literatura nos trópicos. São Paulo: Perspectiva, 1978.

Recebido em: 11 de outubro de 2019.

Aprovado em: 3 de março de 2020. 